\title{
Phytoplankton assemblages in Lake Orta: has functional structure recovered in one of the largest acidic lakes in the world?
}

\author{
Giuseppe MORABITO* \\ National Research Council, Institute of Ecosystem Study, Largo Tonolli, 50, 28922 Verbania-Pallanza, Italy \\ *Corresponding author: g.morabito@ise.cnr.it
}

\begin{abstract}
Lake Orta (Northern Italy) became one of the world's largest acidic lakes, following industrial pollution, beginning in the late 1920s. Prior to pollution, Lake Orta supported a rich and diversified phytoplankton community dominated by diatoms, cyanobacteria and dinoflagellates. Their taxonomic composition was comparable to that of the nearby Lake Maggiore, which provides a useful reference comparison. After pollution, Lake Orta was so acidic and contaminated with trace metals that only a few tolerant phytoplankton species persisted, supplemented by sudden and short living outbursts of occasional colonists. The lake was limed in 1989-1990. This has permitted the gradual recovery of its chemistry and biology, and many phytoplankton species that inhabit Lake Maggiore are now re-appearing in Lake Orta. I tested the two hypotheses that Lakes Orta and Maggiore would now have a similar phytoplankton taxonomic assemblages, and similar diversity of functional groups given their similar morphometry, physical features and trophic states. The two hypotheses were tested by comparing the phytoplankton assemblages of lakes Maggiore and Orta for the first 10 years after liming, i.e. 1990 to 2001. Phytoplankton was classified according the Reynolds'Morpho Functional Groups and five diversity indices were calculated (S, number of units; H, Shannon-Wiener; E, evenness; D, dominance; J, equitability). SHE analysis (an analysis of diversity changes based on the relationship among species richness (S), H Index (H) and evenness (E)) was also carried out, in order to compare the long term trend of both functional groups and taxa biodiversity. Both taxonomic and the functional composition differed in the two lakes, likely because chemical quality have played a role in taxa selection. Moreover, it was quite clear that, during the first post-liming decade, Lake Orta's phytoplankton was characterized by low diversity and evenness and by marked year-to-year fluctuations. However, SHE analysis showed that the colonization rate was higher in Lake Orta than in Lake Maggiore, and that the environmental modifications caused by the liming were opening new ecological niches, allowing some colonists to thrive in the changing, albeit still unusual chemical environment of the lake.
\end{abstract}

Key words: Phytoplankton; liming; functional groups; diversity; long-term trends.

Received: November 2015. Accepted: December 2015.

\section{INTRODUCTION}

Any consideration of the changing structure of the phytoplankton assemblages in Lake Orta, northern Italy, and its decadal evolution, must begin with the knowledge that living and thriving in this lake was extremely challenging for most aquatic organisms for almost 60 years, due to the strong industrial pollution of the lake which started at the end of 1920s. The acidic condition of the whole water mass and the high concentration of toxic metals made Lake Orta's chemical environment so peculiar that only a few adapted organisms were able to survive (see Bonacina (2001) for a complete review of the earlier studies carried out in Lake Orta). Thus the biology of Lake Orta in the $20^{\text {th }}$ century differed from the other deep subalpine Italian lakes, which were experiencing not acid and metal pollution, but eutrophication which affected their biological communities in completely different ways. However, in spite of their different trophic evolution, Ruggiu (1983) concluded that phytoplankton composition of lakes Maggiore, Lugano, Como, Iseo and
Garda were largely dependent on their similar geographic, morphometric and hydrodynamic features, whereas phytoplankton biomass levels were mainly determined by differing nutrient loads. This finding demonstrates that basin morphometry, light quality and intensity, and mixing dynamics play a key role in selecting phytoplanktonic organisms, mostly according to their functional properties, as stated by Reynolds $(1997,2006)$. The same conclusion drawn by Ruggiu (1983) supports the hypothesis that, following the restoration by 1989/1990 liming, the phytoplankton assemblages in Lake Orta would gradually shift towards a structure comparable to that typical of an oligotrophic deep subalpine lake, such as Lake Maggiore, downstream of Lake Orta.

Pre-pollution studies describing the phytoplankton composition of Lake Orta (Parona, 1880; Bonardi, 1885; Giaj-Levra, 1925), as well as the more recent paleolimnological studies support this hypothesis (Ruggiu et al., 1998). The phytoplankton was indeed rich and diverse, with diatoms, cyanobacteria and dinoflagellates the most abundant groups, and with a taxonomic composition com- 
parable to that of Lake Maggiore. Then, as described in many previous papers, the phytoplankton assemblages of Lake Orta were extirpated by copper toxicity within three years of the start of the industrial pollution (Monti 1930). Twenty years later, Baldi (1949) concluded that the lake was still devoid of any recognizable plankton communities, despite some attempts of plankton species to colonize the lake waters. Further studies of the lake's phytoplankton in the 1960s, 1970s and 1980s (Vollenweider, 1963; Bonacina, 1970; Bonacina et al., 1988; Pizzolon et al., 1992), continued to document poor assemblages, characterized by the dominance of few adapted species and by sudden and brief outbursts of occasional colonists, and traits of a normal phytoplankton seasonal succession were not observed.

The liming intervention (1989-1990) dramatically changed the chemical environment, creating, in fact, a "different" lake, one with new opportunities for fresh colonists, and 41 new phytoplankton species appeared just after liming (Morabito et al., 2001). This increase in diversity, a sudden development of the diatoms which had been rare prior to liming, as well as the first sign of a normal successional dynamics, were all seen as signs of the re-establishment of phytoplankton assemblages that typify the deep Italian subalpine lakes (Morabito et al., 2001).

With restored conditions suitable for their survival and growth, the colonization of Lake Orta by phytoplankton could have been quite straightforward, given the proximity of lakes Maggiore and Mergozzo within the same watershed and with comparable characteristics. Moreover, these lakes are all surrounded and connected by a welldeveloped road network, increasing the chance of dispersal of phytoplankton cells or resting stages through human activities (see review by Incagnone et al., 2015). Thus, the first condition for a successful colonization, namely that arrival of colonists to a suitable aquatic environment (Naselli-Flores et al., 2015), was met, as indicated by the increase in the phytoplankton biodiversity after the liming. The analysis of the post-liming phytoplankton assemblages (Morabito et al., 2001) have shown that many of the species that inhabit Lake Maggiore did begin to appear in Lake Orta. It is reasonable to expect that the two lakes, with their similar morphometric features mixing dynamics, light regime, trophic status and climate, should have a similar phytoplankton taxonomic assemblage. I test that hypothesis here. However, the increase of the taxonomic diversity does not necessarily imply, per se, a complete recovery of the functional structure of an assemblage. Therefore, my second hypothesis is that the assemblages are also comparable in the diversity of their functional groups. Because the functional associations are often more responsive to environmental factors than taxonomicbased classification (Kruk et al., 2002), the analysis of functional group diversity, compared to taxonomic diver- sity, should provide a better understanding of how phytoplankton communities have reorganized in Lake Orta after liming, and should provide a useful indication about the pattern and the extent of the recovery of one of the largest acidic lakes in the world.

\section{METHODS}

Here, I compare the phytoplankton assemblages of lakes Maggiore and Orta, for the decade after the liming intervention in Lake Orta, i.e. from 1990 to 2001, the last year with phytoplankton counting data for Lake Orta. The data from Lake Maggiore I use were collected in the framework of Lake Maggiore limnological monitoring programs supported since the late 1970s by the International Commission for the Protection of Swiss-Italian Waters (Commissione Internazionale per la Protezione delle Acque Italo-Svizzere, CIPAIS) and published in annual reports (available at www.cipais.org). Phytoplankton samples were collected at a central sampling site in Lake Maggiore, corresponding to the point of lake's maximum

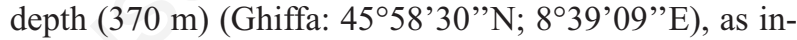
tegrated samples in the $0-20 \mathrm{~m}$ water layer, using an integrating homemade bottle, specifically designed to collect a known amount of water in a fixed layer. In Lake Orta, phytoplankton samples were also collected at the point of maximum depth $(143 \mathrm{~m})$, in front of the town of Pettenasco (4549'11.7'N 8²3’37.4”E) All phytoplankton samples were integrated samples in the $0-20 \mathrm{~m}$ water layer, prepared after mixing discrete samples collected every single meter.

Details about the counting procedure and the literature used for taxonomic identification are reported in Morabito et al. (2001 and 2002).

The data sets for the two lakes used in the present analysis are part of two larger data sets: the Lake Maggiore (1984-2014) and the Lake Orta (1984-2001) longterm series. As described in Morabito et al. (2001 and 2002), in order to reduce the original data matrix to a number of samples easy to manage, considering also the goal of comparing the lakes Orta and Maggiore, where the samples were collected with a different frequency, we used cluster analysis, applied to a dissimilarity matrix. We calculated the dissimilarity between pairs of samples using the Bray and Curtis index computed on biovolumes of identifiable algae, after a square-root transformation of the raw data. The computation of both the Bray and Curtis index and the cluster analysis were performed with PAST (Hammer et al., 2001). A distance matrix and a clustering of samples for each year was obtained. Then, by calculating the average biovolume of the taxonomic units included in every cluster, a second data set, in which every year was represented by groups of samples, was obtained. Because the clusters obtained were describing seasonal changes, seasonal codes were assigned to clusters, as re- 
ported below. Each year was made of four to seven seasonal groups, named as follows: $\mathrm{W}=$ Winter, $\mathrm{ESP}=$ Early Spring, $\mathrm{SP}=$ Spring, LSP=Late Spring, ESU=Early Summer, $\mathrm{SU}=$ Summer, LSU=Late Summer, EAU=Early Autumn, $\mathrm{AU}=$ Autumn and $\mathrm{LAU}=$ Late Autumn. The number of seasonal groups per year depends on the number of original yearly samples and, therefore, on the possibility to identify a higher number of clusters.

To test our hypotheses concerning the taxonomic (hypothesis 1) and functional (hypothesis 2) diversity of Lakes Orta and Maggiore the taxa recorded were grouped in Morpho-Functional Groups (MFG), following the classification proposed by Reynolds et al. (2002), and recently amended by Padisak et al. (2009): in the Morpho-Functional classification, taxa are grouped according to their habitat preferences and tolerances. Each group is identified by a single codon, linked to a peculiar habitat template: the prescriptions by Padisak et al. (2009) were used to assign the species to a group, according to its morphological features and ecological preferences. The sum of the biomasses of every species sharing the same habitat template, gives the total amount of biomass in any given codon (functional group).

Diversity was analyzed with PAST (Hammer et al., 2001), using five indices:

- $S$, number of units (taxa and Morpho-Functional Groups);

- $H$, Shannon-Wiener;

- $E$, evenness;

- $D$, dominance (1-Simpson index. Ranges from 0 when all taxa are equally present to 1 , if one taxon dominates the community completely);

- $J$, equitability (Shannon diversity divided by the logarithm of number of taxa. This measures the evenness with which individuals are divided among the taxa present).

In addition, the SHE analysis was carried out, in order to compare the long term trend of biodiversity. The advantage of the SHE analysis is that it allows the separation of diversity into the two components, species richness $(S)$ and evenness $(E)$, within the same system (Hayek and Buzas, 1997; Mana, 2005): at the same time, their mutual relationships can be described, providing an explanation about the changes in biodiversity, represented by $H$ index.

Hayek and Buzas (1997) demonstrated the relationship among species richness $(S), H$ Index $(H)$ and evenness $(E)$, according to the equation:

$$
\ln E=H-\ln S
$$

The relationship is constant as long as species proportions are constant. Because a change in the proportion of species mirrors a change in diversity, the SHE relationship can be used to infer diversity changes. This is done by plotting the three equation parameters versus the cumulated abundance of the samples (amount of biomass in our case): a change in the slope of the relationship can be interpreted as a shift in biodiversity.

Although the changes in $S, E$ and $H$ are plotted against cumulated biomass, they can be interpreted as variability through time, because of the increase of the cumulated biomass in the system, from sample $s$ to sample $s+1$.

\section{RESULTS}

The aim of this work was to analyze the changes occurred inside of the phytoplankton assemblages of Lake Orta after the liming intervention. Two main hypotheses were suggested to evaluate the recovery of Lake Orta: the first one is that, after liming, the taxonomic composition of phytoplankton should have evolved towards a structure resembling those observed in the deep Italian subalpine lakes, in particular in Lake Maggiore, given that the two lakes have similar morphometric features, mixing dynamics, light regime, trophic status and climate. The second one is that, if a complete recovery of Lake Orta occurred, the phytoplankton assemblages in the two lakes should be comparable even as functional structure.

The results reported below will show that, ten years after the liming, the phytoplankton assemblages of Lake Orta still have a peculiar structure, only partially resembling the taxonomic and the functional composition observed in Lake Maggiore: therefore, the two working hypotheses are not fully supported.

\section{Number of units}

In general, the phytoplankton assemblage of Lake Orta had a lower number of morpho-functional groups (MFGs) than did Lake Maggiore (Fig. 1). There were 25 MFGs found in Lake Maggiore from 1990 to 2001 with a mean of 18 per sample, $v s$ only 20 MFGs in total in Lake Orta, with a mean of 9 per sample. The most abundant 9 MFGs formed $80 \%$ of the total phytoplankton biomass over the decade in L. Maggiore, more than the 6 in L. Orta. However, in L. Orta, the cumulative biomass of only two MFGs (coda A and P) formed almost $50 \%$ of the total biomass over the entire period, whereas the same threshold for L. Maggiore was reached after summing up the biomasses of 5 MFGs (coda MP, R, C, B, Lo). Moreover, there were single periods in Lake Orta (e.g., 1995-1996 and 1997-1998), where only one MFG almost completely dominated the assemblage (Fig 1a), a dominant that changed over time, whereas the dominance structure was more stable in Lake Maggiore (Fig. 1b), for which many MFGs have had similar importance in the phytoplankton assemblage during the decade. Most of the MFGs were present in both lakes, although with a different biomass, but only two of them (coda P and C) dominated in Lake Orta as well as in Lake Maggiore.

Clearly, the phytoplankton assemblages in the two 

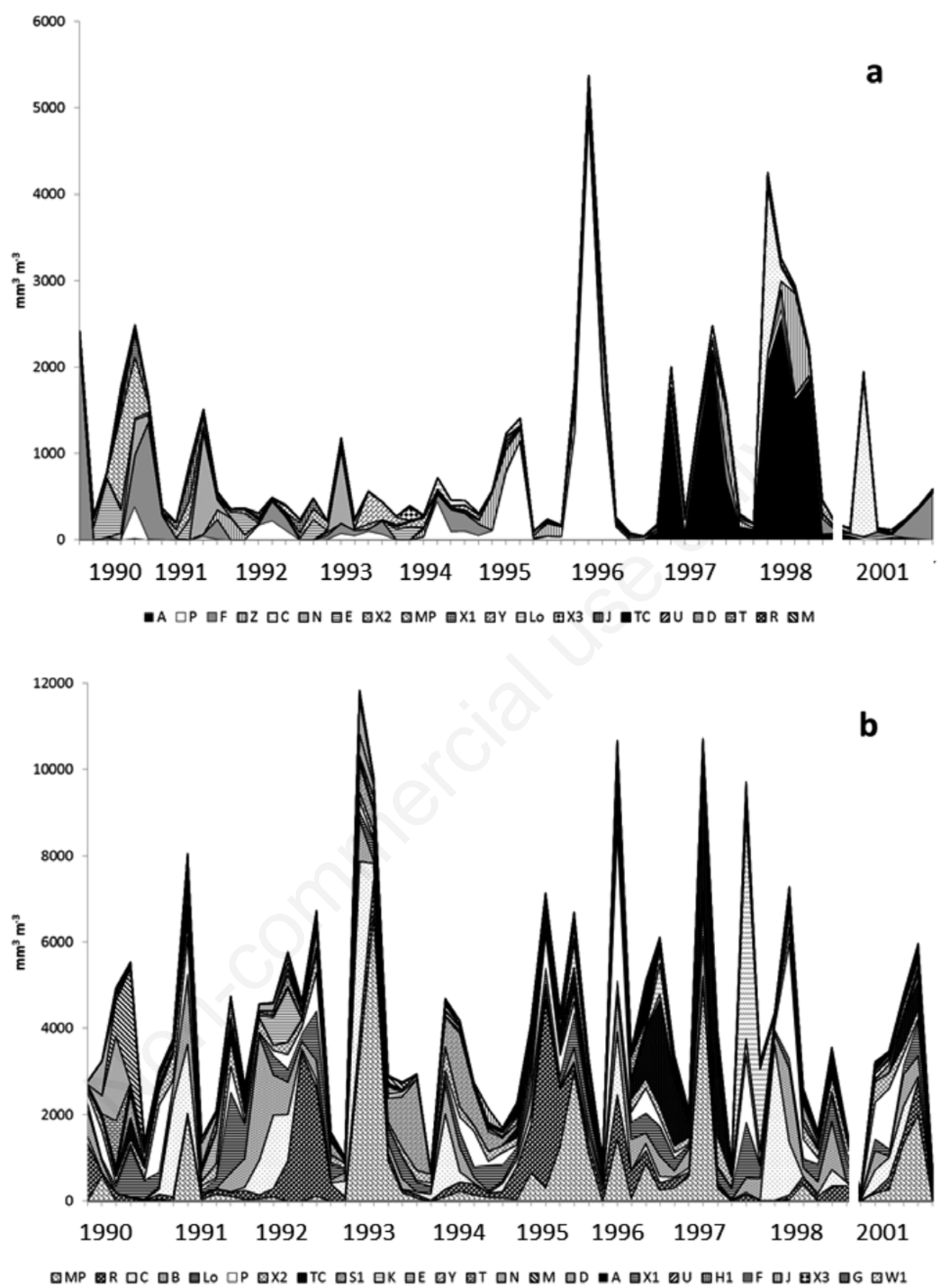

Fig. 1. Decadal fluctuations of the Morpho Functional Groups in lakes Orta (a) and Maggiore (b) in terms of biomass. Thicks on x-axis are the group of samples identified by the clustering algorithm. Data for years 1999 and 2000 are not available for Lake Orta, they was excluded also from the Lake Maggiore data set. The letters indicating the functional groups coda must be read as follows: A, clear, well mixed, base poor lakes; B, vertically mixed, mesotrophic, small-medium lakes; C, mixed, eutrophic small-medium lakes; D, shallow, enriched turbid waters; E, usually small, oligotrophic, base poor lakes or heterotrophic ponds; F, clear epilimnia; G, short, nutrient-rich water columns; H1, dinitrogen fixing Nostocales; J, shallow, enriched lakes ponds and rivers; K, short, nutrient-rich water columns; Lo, summer epilimnia in mesotrophic lakes; M, dielly mixed layers of small eutrophic, low latitude lakes; MP, frequently stirred up, inorganically turbid shallow lakes; N, mesotrophic epilimnia; P, eutrophic epilimnia; R, metalimnia of mesotrophic stratified lakes; S1, turbid mixed layers; T, deep, well mixed epilimnia; TC, eutrophic standing waters; U, summer epilimnia; W1, small organic ponds; X1, shallow mixed layers in enriched condition; X2, shallow, clear mixed layers in meso-eutrophic lakes; X3, shallow, clear, mixed layers; Y, small, enriched lakes; Z, clear, mixed layers. 
lakes were different from a functional point of view, during the first decade after Lake Orta liming. Although these findings partially supported the first working hypothesis, the second one should be rejected. To understand what features of the assemblage structure are mainly responsible for these differences, I examined the functional diversity.

In both lakes the number of MFGs increased significantly with the number of taxa (Fig. 2). This implies that when new taxa enter the phytoplankton assemblage, it becomes more complex from the functional point of view. On the other hand, the relationship is much stronger in Lake Maggiore, implying the rise in functional with taxonomic diversity is comparatively more continuous and regular, whereas in Lake Orta there is an higher dispersion of the points around the regression line, probably indicating that the coupling between taxa number and MFGs number is weaker than in Lake Maggiore: considering the MFG number as the dependent variable, this imply that an increase in taxa does not necessarily mean that new functions are added to the community.

\section{Shannon-Wiener Index and Evenness}

The taxa and MFG numbers were compared in the two lakes. However, a measure of diversity can provide a clearer picture about the structure of the assemblages: Shannon-Wiener Index $(H)$ and Evenness $(E)$ are discussed here, while dominance and equitability will be discussed in the next paragraph. The Shannon-Wiener Index, $H$ (Fig. 3 a,b), calculated on the number of taxa as well as on the number of MFG followed the same yearly cycle for both variables. This is true in both lakes, although in Lake Orta the values recorded were always lower than in Lake Maggiore $\left(H_{\text {taxa }}\right.$ : mean 2.32, $\min .1 .04$, max 3.00 in Lake Maggiore; mean 1.29, min 0.32, max 2.1 in Lake Orta; $H_{M F G}$ : mean 1.93, min. 0.77, max 2.46 in Lake Maggiore; mean 1.14, min 0.26, max 1.82 in Lake Orta) (Fig. $3 a)$. A further difference between the two lakes is that the two indexes (taxa number and MFG number) reached similar mean, minimum and maximum values in Lake Orta, but not in Lake Maggiore. Looking at Lake Maggiore (Fig. 3b), we can see that the two lines are approaching each other moving towards the minimum values: this pattern can explain why in Lake Orta, where the index was lower, the overlapping of the taxa and MFG values is higher (Fig. 3a).

Lower values of the Shannon-Wiener Index can be attributed to the evenness of the samples. In Lake Orta the parameter $E$ (Fig. 3c) fluctuated between 0.1 and 0.6, excluding a single value higher than 0.7 , with a mean value around 0.31 ( 0.27 for taxa and 0.36 for MFG). In Lake Maggiore, evenness (Fig. 3d) oscillated between 0.1 and 0.55 , but the mean value was around 0.34 ( 0.29 for taxa and 0.40 for MFG). Therefore, the lower evenness in Lake Orta, was responsible for the lower Shannon-Wiener val- ues, explaining the high degree of coincidence between the $H$ index of taxa and MFG.

The comparison of the two diversity indexes shows that in Lake Orta the biodiversity was lower and characterized by pronounced fluctuations of the taxa and MFG numbers, where one or few taxa (or MFG) could dominate the phytoplankton assemblage. These results confirm that taxonomic as well as functional groups structure were different in the period examined and that the Lake Orta phytoplankton underwent continuous and rapid changes: therefore none of the working hypotheses can be supported by the comparison of these diversity indices.

\section{Dominance and Equitability}

Patterns of dominance (D) clearly differed between the lakes (Fig. 4 a,b). The mean value of $\mathrm{D}$ in Lake Maggiore was around 0.2 ( 0.19 for taxa, 0.23 for MFG), half the value in Lake Orta (0.43 for taxa, 0.45 for MFG, Fig. 4). At high values of $\mathrm{D}$, a few taxa dominate the assemblage, and in Lake Orta values close or equal to 0.9 were observed on occasion (Fig. 4a). This, together with the remarkable fluctuations, are clear indications that the structure and functions of the phytoplankton assemblage of Lake Orta did not stabilize in the first decade after the liming.
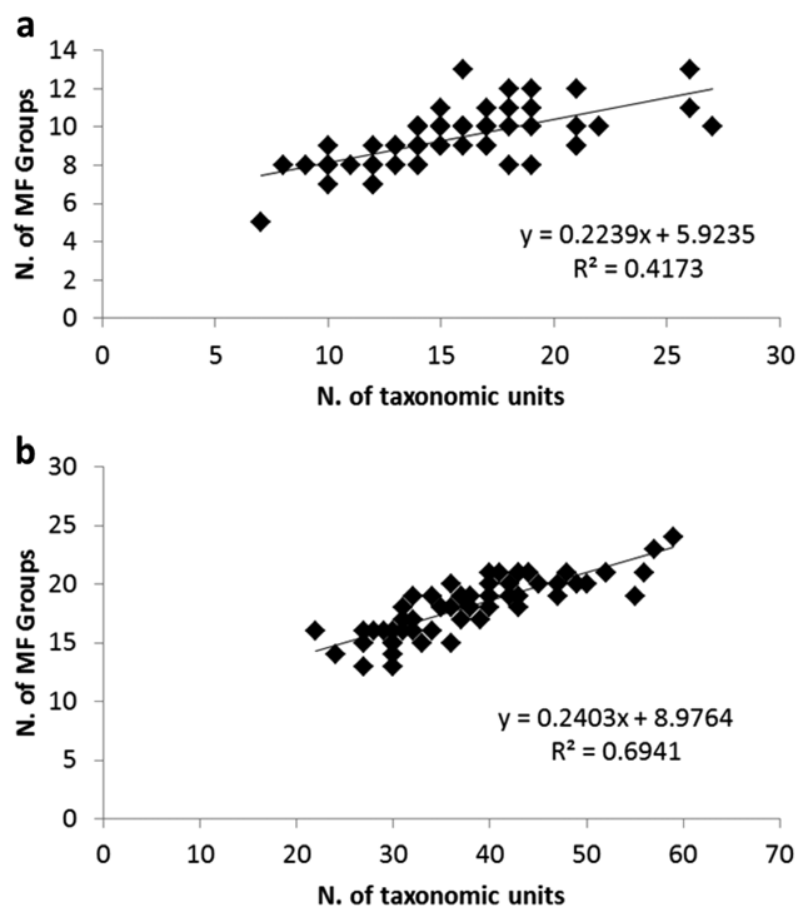

Fig. 2. Relationships between the number of taxonomic units (x-axis) and the number of Morpho Functional Groups (y-axis) in lakes Orta (a) and Maggiore (b). The points represent the groups of samples identified by the clustering algorithm. 
Equitability $(J)$ measures the evenness with which individuals are divided among the taxa or MFG present; therefore, the trends (Fig. 4 c,d) mirror those of the Shannon-Wiener Index and Evenness: relative stability in Lake Maggiore and marked fluctuations in Lake Orta. Number of taxa and MFG followed the same trend, but in Lake Orta this index sometimes fell below 0.2 and it was often below 0.3 . Therefore, its mean value of 0.5 ( 0.48 for taxa and 0.51 for MFG), was lower than in Lake Maggiore, with an equitability index averaging 0.66 (0.64 for taxa and 0.67 for MFG). As stated about diversity indices, the trend and the fluctuations of these two indices do not allow to support the working hypotheses.

\section{SHE analysis}

The trends outlined by the SHE analysis allow to track the changes of the biodiversity in the two lakes: the three diversity parameters $(S, E$ and $H$ ) are plotted (Fig. 5a Lake Orta; Fig. 5b Lake Maggiore) against the logarithm of the total cumulated biomass $(\ln N)$ : because of the increase of the cumulated biomass in the system through time, the trends can be interpreted as time variability. In Lake Maggiore, in terms of MFG (Fig. 5b), there was an increase of the $H$ index, until $\ln N$ (logarithm of the total cumulated biomass) reached a value around ten: this threshold was reached at beginning of 1991. The increasing trend of the three diversity parameters was mainly driven by an increase in the evenness during the first two years of the period (1990-1991), representing the final stage of the recovery of the lake from eutrophication. The following decade (1991-2001) was a period of high stability of the assemblages as biomass as well as biodiversity and evenness: $\ln N$ reached a value around 12.4. Considering the taxonomic composition in Lake Maggiore (Fig. 5b), the increase in biodiversity was constant over the analyzed period and driven by the increase in taxa number: the evenness slightly declined, after the cumulated biomass reached a value around 10.5 , occurring towards the end of 1991.

Lake Orta (Fig. 5a) showed quite a different pattern. For the MFGs, $H$ index increased sharply at the beginning of the period analyzed, corresponding to year 1990. The increase in phytoplankton biomass (ln $N$ passed from 7.8
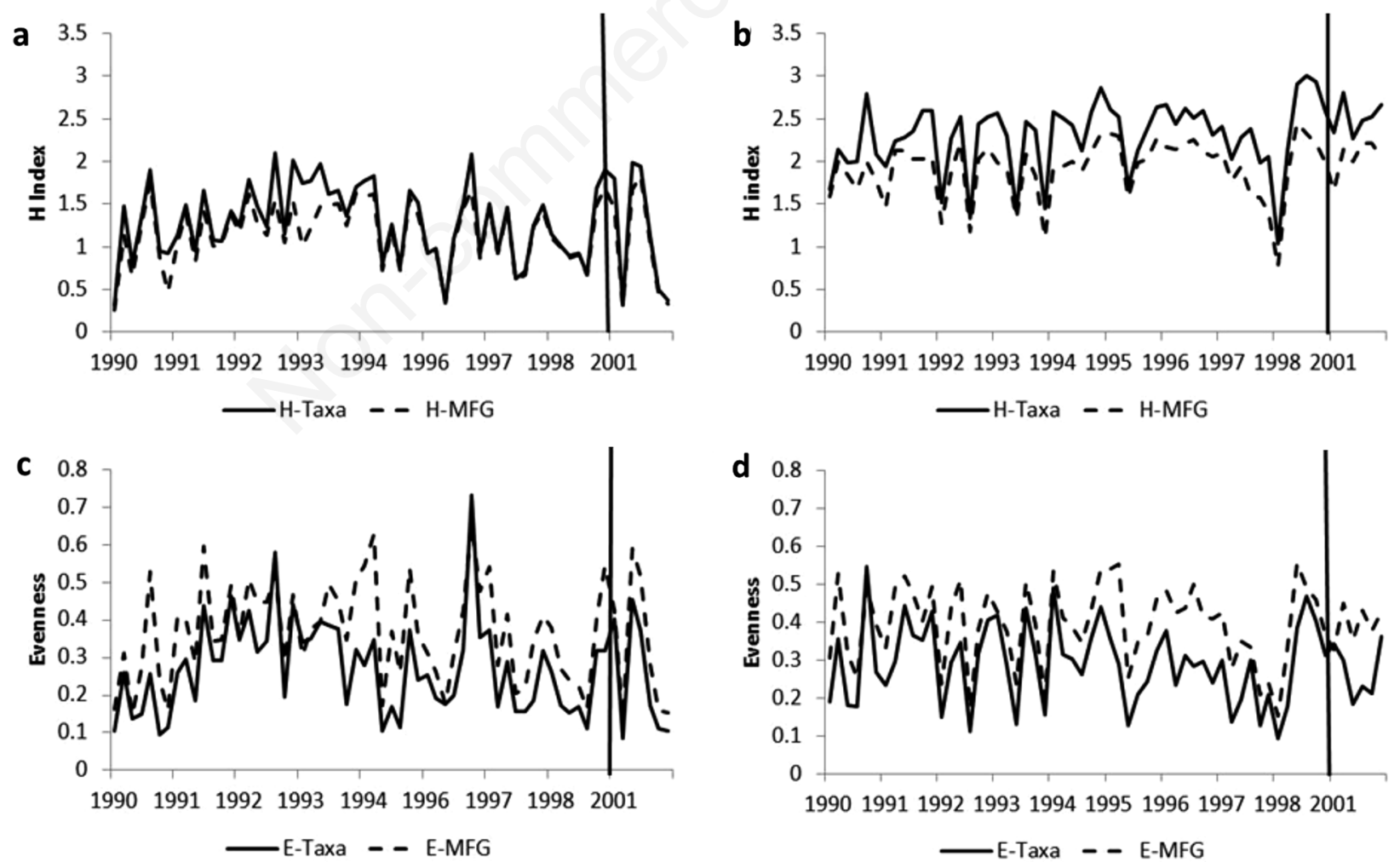

Fig. 3. Decadal trends of Shannon-Wiener index $(H)$ and evenness index $(E)$ in lakes Orta $(a, c)$ and Maggiore (b, d). Trends of the indices for taxonomic units (Taxa) and Morpho Functional Groups (MFG) are represented. The groups of samples identified by the clustering algorithm were used. The ticks on the $\mathrm{x}$-axis correspond to the beginning of each year. The vertical solid line indicates that no data are available for 1999-2000. 
to 8.15 in the same year), immediately following the liming intervention, was initially responsible for this increase, then the functional groups number became stable, but evenness increased, mainly contributing to the further increment of the $H$ index. Evenness declined between 1990 and 1991 (ln $N$ around 9.3), then rose again, until 1995 (ln $N$ around 10), driving the increase of the $H$ index. In 1996, there was a new decline in the evenness and a consequent decline of the Shannon Index. Evenness rose again after 1996 and remained quite stable until 2001 (ln $N$ reached 11): the same trend characterized the $H$ index.

The trend of biodiversity based on taxa shows a continuous increase of the taxonomic units, although this was not followed by a parallel increase of the evenness: this parameter always remained quite low and declined after 1996. The trend of the $H$ index was almost the same already observed for MFGs.

Although showing a clear trend towards an increasing biodiversity, also the SHE analysis seems to confirm the lack of stability which characterized the phytoplankton assemblages in Lake Orta in post-liming decade.

In both lakes, it is clear that an increase of the taxo- nomic diversity not necessarily brings to an increase of the evenness, whereas this parameter better follows the trend of the number of MFGs. This result indicates that, in spite of the differences in the functional groups assemblages, similar processes could have occurred in both lakes, when new MFGs enter the phytoplankton community. However, fitting the relationship between $\ln H$-MFG and $\ln N$ with a simple linear model, there is a strong difference between the slopes of the lines for the two lakes ( $\ln H$-MFG $=0.1117 \ln N+1.3467$ for Lake Maggiore; $\ln H$ $\mathrm{MFG}=0.4218 \ln N-2.1882$ for Lake Orta). This could indicate that a faster colonization process was taking place in Lake Orta, as discussed in the following paragraphs.

\section{DISCUSSION}

Weithoff et al. (2015) suggested a comparative study of taxonomic and functional diversity indices represents a promising approach to study how communities adapt to a changing environment. Our starting hypothesis was that lakes Maggiore and Orta, could host similar phytoplankton assemblages, sharing similar morphometric and phys-
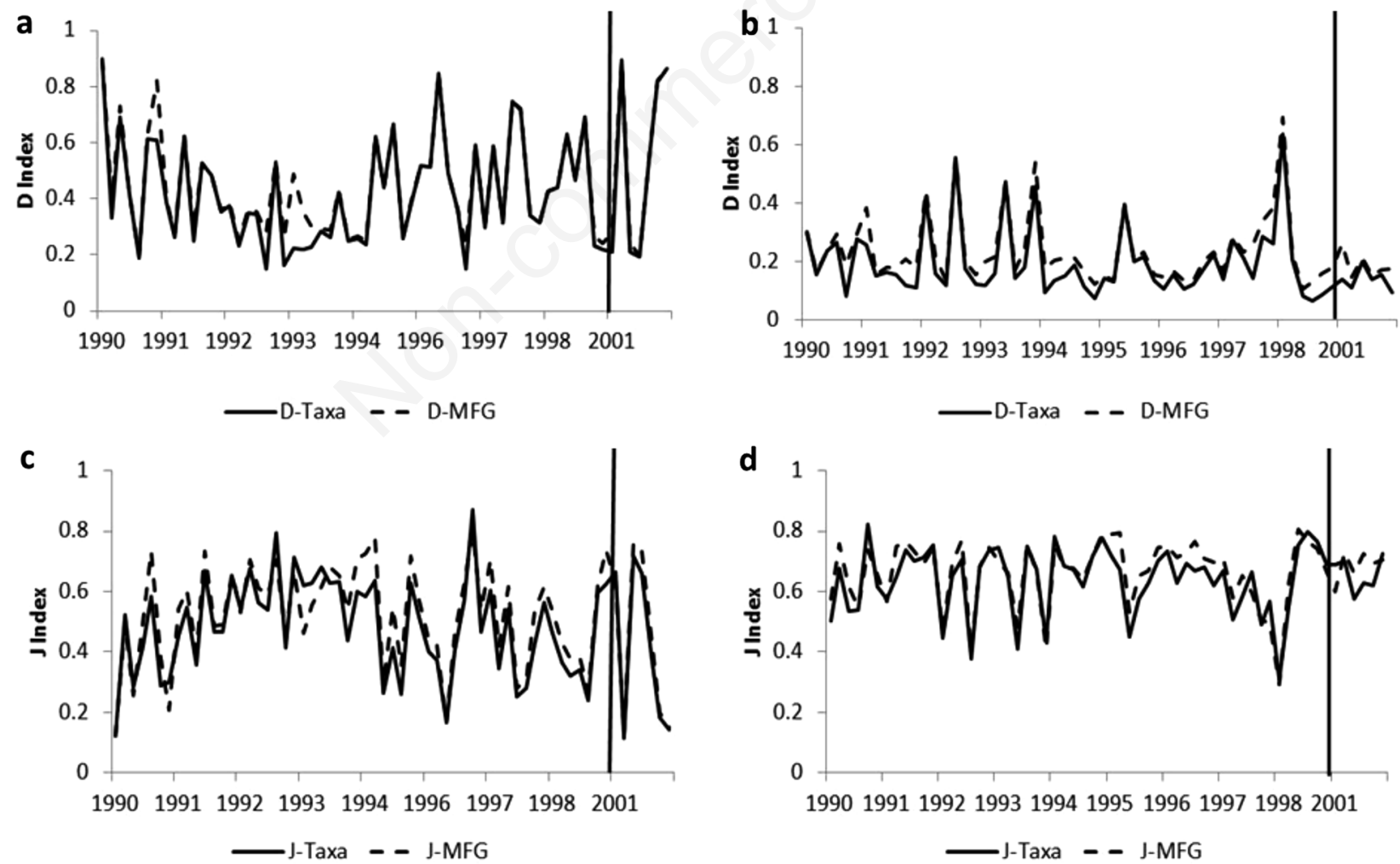

Fig. 4. Decadal trends of Dominance index $(D)$ and Equitability index $(J)$ in lakes Orta $(\mathrm{a}, \mathrm{c})$ and Maggiore (b, d). Trends of the indices for taxonomic units (Taxa) and Morpho Functional Groups (MFG) are represented. The groups of samples identified by the clustering algorithm were used. The ticks on the $\mathrm{x}$-axis correspond to the beginning of each year. The vertical solid line indicates that no data are available for 1999-2000. 
ical features as well as a comparable oligotrophic status, provided that colonization processes in Lake Orta, after the liming, have occurred at a constant rate and the new colonists have been able to thrive in the water column.

The colonization process in the two lakes did seem to follow the same general pattern. Over the time period analysed a linear relationship between the taxonomic and the MFG units was observed, indicating that the arrival of new organisms was generally coupled with an increase of functions. The main difference was that in Lake Maggiore the arrival of new taxonomic units often enriched the functional structure, as indicated by a stronger coupling between the number of the morpho-functional groups units and the number of the taxonomic units. This
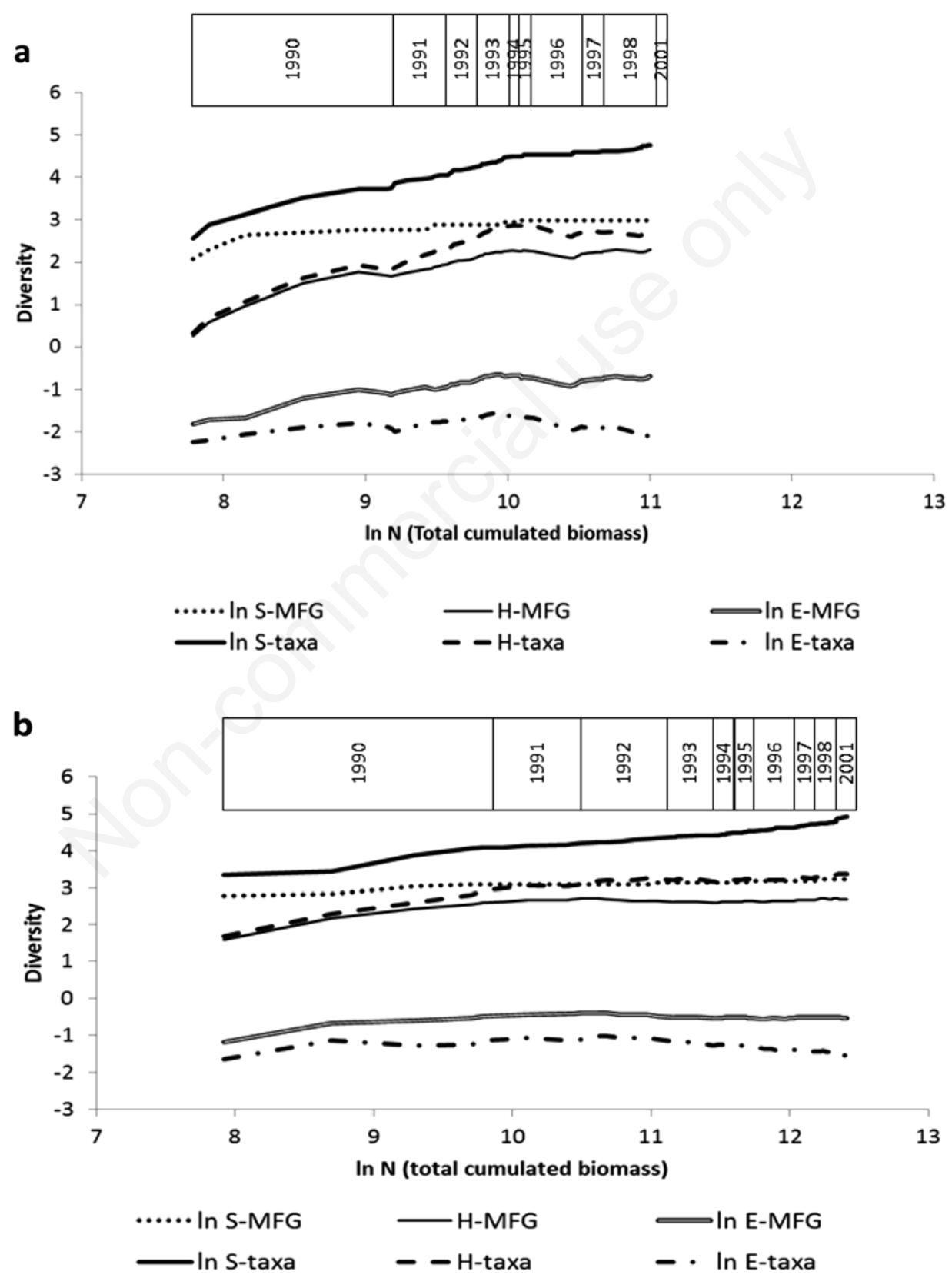

Fig. 5. SHE analysis for lakes Orta (a) and Maggiore (b): on y-axis, $S$ indicates the number of taxa and Morpho Functional Groups, $H$ the Shannon-Wiener index, E the evenness of taxa and Morpho Functional Groups, respectively. The groups of samples identified by the clustering algorithm were used. On x-axis, the cumulated biomass, as logarithm $(\ln N)$. In the upper part of each chart, years are reported: the length of each year is proportional to the increase of the biomass into the system. 
is not evident for Lake Orta, where an increase of taxonomic richness was not always coupled with an increase of the functional richness. This different pattern can indicate that, on one side, many new phytoplankton colonists reaching Lake Orta are not able to set up stable population and, on the other side, that only few functional features can provide successful strategies for colonization and growth in this lake.

Moreover, this difference could explain the fluctuations of the diversity indices observed in Lake Orta. According to Hillebrand and Matthiessen (2009), the fluctuations of the evenness characterizes those communities with a low functional diversity and a low trait divergence. Such a community is probably less resistant to perturbations, because a higher functional diversity improves its ability to cope with a disturbance or stress, conferring stability to the system and a higher efficiency of many ecological processes (Loreau and Hector, 2001).

The differences between the two lakes are even stronger considering what functional groups dominated the phytoplankton assemblages. The dominant MFGs in Lake Maggiore are mostly those expected in a large and deep lakes, with a clear epilimnion and a stable summer stratification: typical representatives of this kind of habitat are the MFG R, including Planktothrix rubescens (De Candolle ex Gomont) Anagnostidis \& Komárek, commonly inhabiting the metalimnetic niche during summer stratification and the coda C, B and P, all represented by large pennate diatoms (Asterionella formosa Hassal, Fragilaria crotonensis Kitton, Aulacoseira spp.), usually inhabiting the deep Italian subalpine lakes, thanks to their high efficiency in the use of underwater light, even during the deep column mixing in winter and to the possibility to slow down their sedimentation during summer, exploiting the strong thermocline at the metalimnetic level (Morabito et al., 2003). The codon MP is also well represented in Lake Maggiore, mostly due to the high biovolumes sometimes reached by Diatoma tenuis C. Agardh: this species is often described as typical of periphytic assemblages, inhabiting streams or lakes' littoral zones (Lim et al., 2001; Antoniades and Douglas, 2002). Its dominance inside of the pelagic assemblage in Lake Maggiore could be due the many tributaries flowing into the lake.

Except for codon P, which was also dominant in Lake Orta, the picture is very different in this lake. The most common MFG was codon A (together with P), followed by coda F, Z, C, N. Three MFGs (A, P, F) amounted to almost $60 \%$ of the total phytoplankton biovolume; codon $P$ was important until 1996, then was replaced by codon A.

The environmental requirements of codon A, typical of clear, deep, base poor lakes (Reynolds et al., 2002) fits well with the pelagic domain of Lake Orta, characterized by alkalinity values lower than in Lake Maggiore. Codon A is typified by Urosolenia eriensis (H.L.Smith) Round
\& R.M.Crawford, which became very abundant in Lake Orta after the liming. Its preference for low alkalinity waters is, probably, not the only environmental factor favoring the establishment of this species: a strong competitive advantage over other phytoplanktonts reasonably derived from its high tolerance to copper (Le Jeune et al., 2006), whose concentrations, although declining, remained quite high during the period 1990-2001.

Typical representatives of codon $\mathrm{F}$ are colonial chlorophytes: also the dominance of this group could be related to the residual toxicity of the waters of Lake Orta, because chlorophytes are commonly described as a metal-tolerant group (Le Jeune et al., 2006). In particular, the mucilaginous colonial forms, such as Westella botryoides (West) De Wildeman, which reached quite high abundances in Lake Orta after the liming, seem to have a competitive advantage in waters polluted by metals. In fact, some experimental results suggest that mucilage played an important role in metal binding (Tien et al., 2005).

The comparison of the diversity indices calculated on taxonomic and functional classification could give some information about the response of the system to environmental forces (Weithoff et al, 2015). Although specific functional diversity indices, such as those based on functional traits (Petchey and Gaston, 2002) were not calculated, the SHE analysis provided some indication. Weithoff et al. (2015), analyzing a 20-years time series of Lake Constance phytoplankton, to determine whether taxonomic diversity and functional diversity exhibit similar or contrasting patterns, describe four different scenarios of synchronous or asynchronous changes of functional and taxonomic diversity. Functional diversity and taxonomic diversity can respond in a similar manner, i.e., when an added taxon increases functional structure. This is the pattern observed in Lake Maggiore as well as in Lake Orta, considering the trends of the $H$ index, as emerged from the SHE analysis. Two main processes can be responsible for the biomass accumulation: the growth of the resident organisms or the arrival of new organisms. Because our results show that biomass accumulation and biodiversity increase are coupled in both lakes, it is reasonable to suppose that the arrival of new species is the driving process, instead of the growth of the resident species. Moreover, the slope of the relationship between $H$ index and cumulated phytoplankton biomass is steeper in Lake Orta than in Lake Maggiore. This indicates that the biodiversity increased faster in Lake Orta in the decade after the liming.

The trend of the evenness shows a different pattern. In both lakes, taxonomic evenness decreased slightly with the increment of the biomass, whereas the functional group index became stable in Lake Maggiore and increased in Lake Orta. These trends can fit within the second scenario described by Weithoff et al. (2015), where decreasing taxonomic diversity is associated with either 
constant or increasing functional diversity. Two relationships exist, considering that the decrease in taxonomic diversity could be coupled with a constant functional diversity or with an increasing functional diversity. The first relationship seems to have occurred in Lake Maggiore, suggesting, according to Weithoff et al.(2015), that competitive exclusion within groups of similar species took place, although different functional properties were maintained into the system, thus conserving its effectiveness to cope with the environment. On the other hand, in Lake Orta, the decrease in taxonomic diversity associated with an increase in functional groups diversity may suggest (Weithoff et al., 2015) that the environment is changing and the potential establishment of new niches could occur. This pattern is in agreement with the observation that the evenness of MFGs increased at a faster rate than in Lake Maggiore, probably indicating that a rapid colonization process was taking place.

\section{CONCLUSIONS}

The phytoplankton assemblages in Lake Orta underwent strong changes during the period 1990-2001, following the chemical modifications of the water column that occurred after the liming intervention. Fast colonization processes started soon after the liming and many new taxa appeared. An earlier paper analysed the recovery pattern in terms of general phytoplankton structure, examining the changes of the biodiversity, total biomass, chlorophyll $a$, abundance and species composition (Morabito et al., 2001). Here my aim was to compare the phytoplankton assemblages of Lake Orta with those inhabiting in Lake Maggiore, focusing not only on the taxonomic composition, but also on the functional structure. In particular, two main questions were examined: 1) did Lake Orta phytoplankton evolved towards a taxonomic assemblage similar to that of Lake Maggiore, given that the two lakes have similar morphometric features, mixing dynamics, light regime, trophic status and climate? 2) Are these assemblages also comparable in terms of functional groups diversity? Moreover, can the analysis of functional groups diversity, compared to taxonomic diversity, provide a better understanding of how phytoplankton communities might have reorganized in Lake Orta?

The first hypothesis was not fully supported. Except for the return of diatoms among the dominant species, both the taxonomic and the functional composition differed in the two lakes, although the most abundant taxa in Lake Maggiore, as well as in Lake Orta, are characteristic of deep and clear water columns. However, the ecological preferences shown by the dominant functional groups in Lake Orta indicate that differences in the water chemistry (low alkalinity and dissolved metals) may have played a role in taxa selection.

As concerns the second hypothesis, during the first post-liming decade, Lake Orta phytoplankton was characterized by low diversity and evenness and by marked year-to-year fluctuations. On the other hand, the SHE analysis showed that the colonization rate was higher in Lake Orta than in Lake Maggiore and that the environmental modifications due to the liming were opening new ecological niches.

In summary, the recovery of Lake Orta was coupled with a high potential for the colonization by new taxa, but only some selected colonists were able to set up and thrive in an environment undergoing a continuous changing and showing peculiar chemical conditions for the whole investigated period. Unfortunately, phytoplankton data after 2001 are not available; however, some in situ fluorometric measurements, carried out between 2008 and 2013 (unpublished data) still shown a significant dominance of chlorophytes, thus confirming that phytoplankton assemblages in Lake Orta are still evolving quite a different structure in comparison to that characterizing Lake Maggiore.

\section{REFERENCES}

Antoniades D, Douglas MSV, 2002. Characterization of high arctic stream diatom assemblages from Cornwallis Island, Nunavut, Canada. Can. J. Bot. 80:50-58.

Baldi E, 1949. [Il Lago d'Orta, suo declino biologico e condizioni attuali].[Article in Italian]. Mem. Ist. Ital. Idrobiol 5:145-188.

Bonacina C, 1970. [Il Lago d'Orta: ulteriore evoluzione della situazione chimica e della struttura della biocenosi planctonica].[Article in Italian]. Mem. Ist. Ital. Idrobiol. 26:141-204.

Bonacina C, 2001. Lake Orta: the undermining of an ecosystem. J. Limnol. 60:53-59.

Bonacina C, Bonomi G, Barbanti L, Mosello R, Ruggiu D, 1988. Recovery of an industrially acidified, ammonium and heavy metals polluted lake (Lake d'Orta, N. Italy) due to the adoption of treatment plants. Verh. int. Ver. Limnol. 23:535-544.

Bonardi, E, 1885. [Sulle Diatomee del Lago d'Orta].[Article in Italian]. Boll. Scientifico 7:1-8.

Giaj Levra, P, 1925. [Diatomee del Lago d'Orta].[Article in Italian]. Atti Soc. Ligustica Sci. Lett. N.S. 5:66-82.

Hayek L-AC, Buzas MA, 1997. Surveying natural populations. Columbia University Press: 563 pp.

Hammer Ø, Harper DAT, Ryan PD, 2001. PAST: Paleontological Statistics Software Package for education and data analysis. Palaeontologia Electronica 4:9.

Hillebrand H, Matthiessen B, 2009. Biodiversity in a complex world: consolidation and progress in functional biodiversity research. Ecol. Lett. 12:1405-1419.

Kruk C, Mazzeo N, Lacerot G, Reynolds CS, 2002. Classification schemes for phytoplankton: a local validation of a functional approach to the analysis of species temporal replacement. J. Plankt. Res. 24:901-912.

Incagnone G, Marrone F, Robba L, Barone R, Naselli-Flores L, 2015. How do freshwater organisms cross the "dry ocean"? A review on passive dispersal and colonization processes with a special focus on temporary ponds. Hydrobiologia 750:103-123. 
Le Jeune AH, Charpin M, Deluchat V, Briand JF, Lenain JF, Baudub M, Amblard C, 2006. Effect of copper sulphate treatment on natural phytoplanktonic communities. Aquatic. Tox. 80:267-280.

Lim DSS, Kwan C, Douglas MSV, 2001. Periphytic diatom assemblages from Bathurts Island, Nunavut, Canadian High Arctic: an examination of community relationships and habitat preferences. J. Phycol. 37:379-392.

Loreau M, Hector A. 2001. Partitioning selection and complementarity in biodiversity experiments. Nature 412:72-76.

Mana D, 2005. A test application of the SHE method as a biostratigraphic parameter. Geo. Alp. 2:99-106.

Monti R, 1930. [La graduale estinzione della vita nel Lago d'Orta].[Article in Italian]. Ist. Lomb. Sc. Lett. 58:1-22.

Morabito G, Oggioni A, Panzani, P, 2003. Phytoplankton assemblage at equilibrium in large and deep subalpine lakes: a case study from Lago Maggiore (N. Italy). Hydrobiologia 502: 37-48.

Morabito G, Ruggiu D, Panzani P, 2001. Trends of phytoplankton characteristics and their communities in pre- and postliming time in Lake Orta (1984-1998). J. Limnol. 60:91-100.

Morabito G, Ruggiu D, Panzani P, 2002. Recent dynamics (1995-1999) of the phytoplankton assemblages in Lago Maggiore as a basic tool for defining association patterns in the Italian deep lakes. J. Limnol. 61:129-145.

Naselli-Flores L, Termine R, Barone R, 2015. Phytoplankton colonization patterns. Is species richness depending on distance among freshwaters and on their connectivity? Hydrobiologia 764:103-113.

Padisak J, Crossetti LO, Naselli-Flores L, 2009. Use and misuse in the application of the phytoplankton functional classification: a critical review with updates. Hydrobiologia 621:1-19.

Parona C, 1880. [Prime ricerche intorno ai protisti del Lago d'Orta].[Article in Italian]. Boll. Scientifico Pavia 2:17-26.
Petchey OL, Gaston KJ, 2002. Functional diversity (FD), species richness and community composition. Ecol. Lett. 5:402-411.

Pizzolon L, Ruggiu D, Morabito G, 1992. Primary production and phytoplankton communities in the acidified Lake Orta (N. Italy) after the removal of ammonia pollution. Mem. Ist. Ital. Idrobiol. 51:29-52.

Reynolds CS, 1997. Vegetation processes in the pelagic: a model for ecosystem theory. Ecology Institute, Oldendorf/Luhe: $371 \mathrm{pp}$.

Reynolds CS, 2006. The ecology of phytoplankton. Cambridge University Press: 552 pp.

Reynolds CS, Huszar V, Kruk C, Naselli-Flores L, Melo S, 2002. Towards a functional classification of the freshwater phytoplankton. J. Plankt. Res. 24:417-428.

Ruggiu D, Luglié A, Cattaneo A, Panzani P, 1998. Paleoecological evidence for diatom response to metal pollution in Lake Orta (N. Italy). J. Paleolimnol. 20:333-345.

Ruggiu D, Morabito G, Panzani P, Pugnetti A, 1998. Trends and relations among basic phytoplankton characteristics in the course of the long-term oligotrophication of Lake Maggiore (Italy). Hydrobiologia 369/370:243-257.

Tien, CJ, Sigee, DC, White, KN, 2005. Copper adsorption kinetics of cultured algal cells and freshwater phytoplankton with emphasis on cell surface characteristics. J. Appl. Phycol. 17:379-389.

Vollenweider RA, 1963. [Studi sulla situazione attuale del regime chimico e biologico del Lago d'Orta].[Article in Italian]. Mem. Ist. Ital. Idrobiol. 16:21-125.

Weithoff G, Rocha M, Gaedke U, 2015. Comparing seasonal dynamics of functional and taxonomic diversity reveals the driving forces underlying phytoplankton community structure. Freshwater Biol. 60:758-767. 